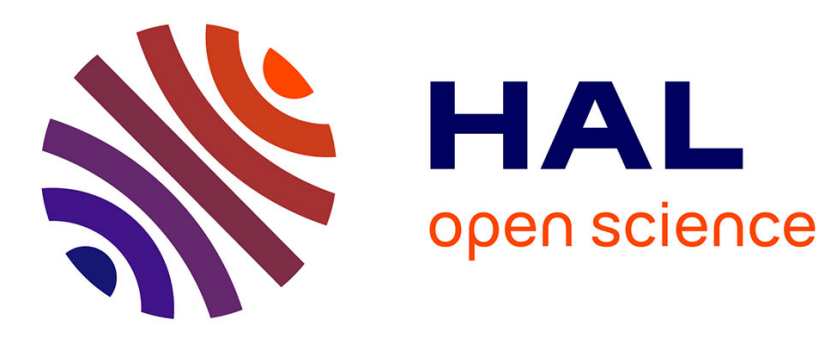

\title{
Dynamin 2 and human diseases
}

Anne-Cécile Durieux, Bernard Prudhon, Pascale Guicheney, Marc Bitoun

\section{To cite this version:}

Anne-Cécile Durieux, Bernard Prudhon, Pascale Guicheney, Marc Bitoun. Dynamin 2 and human diseases. Journal of Molecular Medicine, 2010, 88 (4), pp.339-350. 10.1007/s00109-009-0587-4 . hal02451106

\section{HAL Id: hal-02451106 https://hal.science/hal-02451106}

Submitted on 23 Jan 2020

HAL is a multi-disciplinary open access archive for the deposit and dissemination of scientific research documents, whether they are published or not. The documents may come from teaching and research institutions in France or abroad, or from public or private research centers.
L'archive ouverte pluridisciplinaire HAL, est destinée au dépôt et à la diffusion de documents scientifiques de niveau recherche, publiés ou non, émanant des établissements d'enseignement et de recherche français ou étrangers, des laboratoires publics ou privés. 
1. Durieux

\section{Dynamin 2 and human disease}

Anne-Cécile Durieux ${ }^{1,2}$, Bernard Prudhon ${ }^{1,2}$, Pascale Guicheney ${ }^{2,3}$, Marc Bitoun ${ }^{1,2}$

1. Inserm, UMR S974, Institut de Myologie, Groupe Hospitalier Pitié-Salpêtrière, Paris, F75013, France.

2. UPMC Univ Paris 06, IFR14, Paris, F-75013, France.

3. Inserm, UMR S956, Groupe Hospitalier Pitié-Salpêtrière, Paris, F-75013, France.

Abstract: 145 words.

Manuscript: 3761 words.

Number of Figures: 2.

Number of Tables: 1.

\section{Corresponding Author:}

Dr. Marc Bitoun, UMR_S974, Institut de Myologie, Groupe Hospitalier Pitié-Salpêtrière, 75013, Paris, France.

E-mail: m.bitoun@institut-myologie.org

Tel: $33(0)$ 1.42.16.57.18

Fax: $33(0)$ 1.42.16.57.00 


\section{Abstract}

Dynamin 2 (DNM2) mutations cause autosomal dominant centronuclear myopathy (CNM), a rare form of congenital myopathy, and intermediate and axonal forms of CharcotMarie-Tooth disease (CMT), a peripheral neuropathy. DNM2 is a large GTPase mainly involved in membrane trafficking through its function in the formation and release of nascent vesicles from biological membranes. DNM2 participates in clathrin-dependent and clathrinindependent endocytosis and intracellular membrane trafficking (from endosomes and Golgi apparatus). Recent studies have also implicated DNM2 in exocytosis. DNM2 belongs to the machinery responsible for the formation of vesicles and regulates the cytoskeleton providing intracellular vesicle transport. In addition, DNM2 tightly interacts with, and is involved in the regulation of actin and microtubule networks, independent from membrane trafficking processes. We summarize here the molecular, biochemical and functional data on DNM2 and discuss the possible pathophysiological mechanisms via which DNM2 mutations can lead to two distinct neuromuscular disorders.

Key Words: dynamin 2, centronuclear myopathy, Charcot-Marie-Tooth neuropathy, endocytosis, cytoskeleton. 
Dynamin 2 (DNM2) belongs to a superfamily of large GTPases, including three classical dynamins and several dynamin-like proteins, which are involved in a wide range of cell functions [1]. The importance of DNM2 was emphasized in 2005 with the demonstration of DNM2 gene mutations causing two distinct human diseases [2, 3]. Our purpose is to review the molecular and functional data on DNM2 to highlight the possible pathophysiological hypotheses in DNM2-related diseases. Knowledge of the dynamins, especially of their molecular and biochemical properties, mainly comes from numerous studies of dynamin 1 (DNM1) [4]. However, we have focused this review on DNM2 since several studies have clearly demonstrated notable differences between DNM1 and DNM2 [5-9]. Moreover, DNM1 and DNM2 seem to be involved in different membrane trafficking processes in cells expressing the two proteins $[10,11]$.

\section{DNM2 gene organization and isoforms}

DNM2, one of three classical dynamins, was initially identified in rat liver and brain cDNA libraries [5, 12]. A human homologue was thereafter identified by screening of a fibroblast library [13]. The human transcript (3.6 kilobases) is ubiquitously expressed, with higher abundance in heart and skeletal muscle [13]. Human DNM2 is encoded by the DNM2 gene located on the short arm of chromosome 19 (19p13.2). The gene is composed of 22 exons in a 114-kilobase region. Four isoforms are expressed by the DNM2 gene using a combination of two alternative splice sites (Figure 1A). Isoforms 1, 2, 3 and 4 are also known as isoforms aa, ba, ab and bb, respectively [14]. Exons 10 and 10bis have the same length (139 base pairs encoding the amino-acids 399-445 in the middle domain) and are alternatively spliced. In addition, the exon 13bis (12-base pair length) can be spliced leading to the translation of proteins of 866 or 870 amino-acids (Figure 1) without or with the GEIL 
sequence at position 516-519 in the C-terminal part of the middle domain. The expression of the four isoforms have been assessed in a panel of rat tissues including brain, heart, kidney, liver, lung, pancreas and testis [14]. The human tissue expression pattern is unknown, but we have shown expression of the four isoforms in skeletal muscle and peripheral nerve [15]. Specific functions of these isoforms will be discussed below.

\section{DNM2 structure and regulation}

The 98 kDa DNM2 is a large GTPase composed of a N-terminal GTPase domain, a middle domain, a pleckstrin homology domain (PH), a GTPase effector domain (GED) and a C-terminal proline rich domain (PRD) (Figure 1B). The catalytic GTPase domain is responsible for GTP binding and hydrolysis, whereas the middle domain is involved in DNM2 self-assembly [16] and in GTP hydrolysis-induced conformational change of the protein [17]. The $\mathrm{PH}$ domain interacts with membrane phosphoinositides and therefore involved in the targeting of dynamin to plasma or Golgi membranes [18]. Klein and collaborators reported that the DNM2-PH domain displays phosphoinositide binding affinity following the order; $\mathrm{PI} 4,5 \mathrm{P} 2 \approx \mathrm{PI} 3,4,5 \mathrm{P} 3 \approx \mathrm{PI}, 4 \mathrm{P} 2>\mathrm{PI} 4 \mathrm{P} \approx \mathrm{PI} 3 \mathrm{P}$, and $\mathrm{DNM} 2$ oligomerization appears crucial for high affinity [19]. The GED probably participates in the self-assembly of DNM2 and acts as a GTPase-activating protein (GAP) [20]. The PRD contains multiple Src homology 3 (SH3) binding motifs and mediates multiple protein-protein interactions (Table 1).

In vitro at high ionic strength, DNM2 is in monomer-tetramer equilibrium. At low ionic strength, DNM2 self-assembles into higher order aggregates leading to a drastic increase in GTPase activity [21, 22]. Microtubules or phospholipid vesicles, especially those containing PI4,5P2, also induce self-assembly and increase DNM2 GTPase activity [6, 21, 
23]. Purified from baculovirus, GTP-bound and GDP-bound monomer DNM2 has Kd values of 13.2 and $7.1 \mu \mathrm{M}$, respectively, with GTPase activity of $37 \mathrm{nmol} / \mathrm{mg} / \mathrm{min}$. When in an oligomeric state, the GTPase activity of DNM2 markedly increased and Kd values decreased [24]. DNM2 basal activity appears 10-fold higher than for DNM1 probably due to the greater propensity of DNM2 to self-assemble and a higher affinity for GTP $(\mathrm{Km}=12 \mu \mathrm{M})$ [21]. When compared to small GTPases, DNM2 exhibits a relatively low affinity for GTP but high intrinsic rates of GTP hydrolysis.

DNM2 activity is regulated by post-translational modifications. DNM2 becomes phosphorylated on Tyr231 (middle domain) and Tyr597 (PH domain) through Src-mediated phosphorylation, leading to its association with caveolin and thus albumin endocytosis [25]. Similarly, IL5-induced DNM2 phosphorylation leads to redistribution of DNM2 within endocytic vesicles and is required for IL5 receptor internalization [26]. In contrast, dopamine leads to the dephosphorylation of DNM2 by increasing protein phosphatase 2A activity, necessary for dopamine-induced $\mathrm{Na}^{+} \mathrm{K}^{+}$-ATPase endocytosis [27]. S-nitrosylation of Cys86 (GTPase domain) and Cys607 (PH domain) by nitric oxide (NO) increases DNM2 GTPase activity and endocytosis [28]. Finally, regulation of DNM2 by proteolysis under pathological condition has also been reported [29]. Sever et al. identified a cathepsin L cleavage site at positions 355-360 in the middle domain (Figure 1B). In a mouse model of kidney disease, cathepsin L induction leads to the cleavage of the cytoplasmic DNM2 and then actin reorganization in renal podocytes, filtration impairment and proteinuria [29]. It remains to be determined whether such proteolytic regulation occurs in other tissues.

Phosphorylation of DNM1 by protein kinase $\mathrm{C}$ (PKC) increases $\mathrm{Ca}^{2+}$ binding to the protein, which in turn inhibits DNM1 stimulated GTPase activity [30]. Although DNM2 is not a substrate of PKC and does not bind $\mathrm{Ca}^{2+}[5]$ it was demonstrated that $\mathrm{Ca}^{2+}$ also inhibits 
DNM2 GTPase activity $\left(\mathrm{IC}_{50}=150 \mu \mathrm{M}\right)$ and receptor mediated endocytosis in Hela cells [31]. This may have physiological importance in excitable cells like neurons and muscle fibers.

It is still largely unknown how the expression of DMN2 is regulated. In rat, DNM2 is up-regulated during normal pancreatic development after birth [32] but not in the liver [12] or the brain [33]. In mouse, treatment with opioid agonist results in increased DNM2 protein content in the spinal cord [34, 35] whereas opioid antagonist decreases DNM2 abundance [35, 36]. These changes in the level of DNM2 expression are inversely correlated with opioid receptor density at the plasma membrane, suggestive of feed-back regulation. A similar type of regulation has also been described in brain [37].

\section{DNM2 function}

1. Endocytosis. DNM2 has been implicated in the formation of clathrin-coated pits [21]. In the cytosol, DNM2 forms a complex with sorting nexin 9 (SNX9) and fructose-1,6bisphosphate aldolase [38, 39]. Phosphorylation of SNX9 releases aldolase from the SNX9DNM2 complex which is now competent for membrane targeting [39, 40]. DNM2 anchorage to the membrane occurs via interaction with PI4,5P2 membrane phosphoinositide [41] and BAR (Bin1/Amphiphysin/RVS167) domain proteins; amphiphysin 1, amphiphysin 2, and SNX9 (Table 1) in curved sites of the membranes. Subsequently, DNM2 co-localizes with clathrin before and during the internalization of the coated vesicle [7]. This suggests that DNM2 may play a role not only in the release, but also in the first steps of vesicle formation, as recently shown in the turnover of intermediates during the maturation of clathrin-coated pits [42]. During this process, DNM2 forms an oligomer helical structure around the neck of the nascent vesicles [21] and GTP hydrolysis is associated with the release of the vesicles. 
DNM2 is also involved in clathrin-independent endocytosis by its role in the formation of the phagosomes in macrophages and Sertoli cells $[43,44]$ and caveolae in hepatocytes and endothelial cells $[45,46]$. Predescu et al. described a protein complex, including DNM2, intersectin and SNAP-23, that was important for the fission and internalization of caveolae [47]. In caveolae, DNM2 also interacts with endothelial nitric-oxide synthase (eNOS) in bovine aortic endothelial cells [48] where DNM2 may regulate eNOS activation and the NO signalling cascade [48-51]. DNM2 also participates in coat-independent endocytosis processes, i.e. micropinocytosis and macropinocytosis, by which fluid droplets and specific membrane components are internalized [52, 53].

Altogether, these data demonstrate a role for DNM2 in clathrin- and caveolaedependent endocytosis as well as coat-independent endocytosis, and in regulating several important cellular processes including signal transduction, cholesterol homeostasis, plasma membrane composition and turnover, cell migration and entry of pathogens.

2. Intracellular membrane trafficking. DNM2 targets to the Golgi apparatus where it is predominantly localized in the trans-Golgi network (TGN) [54]. Anti-DNM2 antibody injection and over-expression of DNM2 mutants impair vesicle formation from the TGN [5557]. Association of DNM2 with cortactin, by an arf-1 and actin-dependent mechanism, and with syndapin 2, is required for trafficking of nascent vesicles from the TGN [58, 59]. DNM2 is also found at the clathrin-coated buds of early endosomes [60] and in late endosomes in Hela cells, located to the tubulo-vesicular appendices [61]. In these two cases, interfering DNM2 mutant impairs the recycling of components from the endosomal system towards the plasma membrane or TGN $[60,61]$. These data highlight the role of DNM2 in the secretory pathway and in the sorting of cell components from the Golgi apparatus and endosomal compartment. 
3. Exocytosis. In neuroendocrine cells, monomers of DNM2 are associated with the membrane of secretory chromaffin granules in a complex including syntaxin, a member of the exocytosis machinery [62]. DNM2 also interacts and co-localizes with complexin I, a SNARE regulatory protein [63]. Therefore, DNM2 may participate in endocytosis-exocytosis coupling as suggested in mouse pancreatic $\beta$-cells [64]. However, a role for DNM2 in exocytosis alone has been reported. During cell-mediated killing by natural killer (NK) cells, DNM2 colocalizes with lytic granules after NK cell activation, and is required for fusion of the granules with the plasma membrane [65]. Similarly in macrophages, focal exocytosis is blocked after anti-DNM2 antibody microinjection [66] and DNM2 GTPase activity regulates the fusion of secretory vesicles at the plasma membrane [67]. Further studies will be necessary to precisely identify the molecular role played by DNM2 in the exocytosis machinery.

4. Actin network. Actin-based dynamic processes are crucial for late stage endocytosis and vesicle formation, and DNM2 interacts with several actin-binding proteins. Direct interactions have been identified with Abp1 (actin-binding protein 1) [68] and cortactin [69, 70]. Abp1 is a Src kinase which provides a physical bridge between the endocytosis machinery and the cortical actin network, and cortactin is a component of the clathrin-mediated endocytosis machinery [71]. In addition, DNM2 is a component of actin-based motile vesicles (actin comets) [72, 73] which provide transport through the cytoplasm for vesicles formed by the Golgi apparatus or plasma membrane. Expression of DNM2-K44A mutant, defective for the GTPase activity, strongly reduces the number, length and velocity of the comets [72, 73].

Interaction between DNM2 and the actin cytoskeleton may have another cytoskeletal role such as in the formation of membrane tubules and protrusions. Furthermore, a recent study showed the crucial function played by the DNM2-cortactin complex in the global 
organisation and remodelling of the actomyosin cytoskeleton [74]. In addition, DNM2 is present in cortical ruffles and lamellipodia, both important in cell migration $[14,69]$. The supramolecular complex including DNM2, cortactin and Arp2/3 mediates the reorganization of actin allowing lamellipodia formation at the leading edge of migrating cells [75]. Disruption of DNM2 function by DNM2-K44A mutant or small interfering RNA (siRNA), inhibits the formation of lamellipodia [76]. Similarly, under PDGF stimulation, DNM2 is concentrated within the leading ruffles of migrating fibroblasts where it co-localizes with cortactin [69]. To allow cell migration, DNM2 participates in disassembly of focal adhesions, as well as $\beta$-integrin internalization at the rear of the cell $[77,78]$. Additionally, DNM2 is enriched in specialized membrane protrusions such as podosomes and invadipodia. Podosomes represent attachment sites between cells and substratum [79] and invadipodia are focalized matrix degradation sites [80]. Inhibition of DNM2 diminishes the amount of such structures [80]. It has also been shown that DNM2 regulates the formation of actin stressfibers by interaction with the cell surface heparin sulphate proteoglygan syndecan-4 [81] Expression of DNM2-mutant, truncated for the PRD domain mediating interaction with cortactin, increases the number of actin-stress fibers, which is associated with abnormal cell shape [69].

5. Microtubule network and MTOC. It is noteworthy that the first isolated dynamin, i.e. DNM1, was initially reported as a microtubule associated protein [4]. A similar binding property has been evidenced for DNM2 in vitro [21] and the binding region was located to the PRD [6, 82]. More recently, it was shown that down-regulation of DNM2 by siRNA increases the amount of acetylated tubulin, a more stable form of tubulin in microtubules, and reduces their growing capacity [83], suggesting that DNM2 may regulate the polymerizationdepolymerization equilibrium of microtubules. Through its interaction with microtubules, 
DNM2 appears involved in Golgi apparatus cohesion [83]. Moreover, DNM2 has been identified as a component of the centrosome, the main microtubule organizing center (MTOC), where it binds to $\gamma$-tubulin [84]. The centrosome consists of a pair of centrioles embedded in a filamentous pericentriolar matrix, where $\gamma$-tubulin is essential for microtubule nucleation. The function played by DNM2 at the centrosome is still unknown, but DNM2 silencing by siRNA suggests a role in centrosome splitting [84]. Likewise, participation of DNM2 in all the phases of mitosis has also been reported. DNM2 is detected in the 2 MTOC during early prophase, along the mitotic spindle during metaphase and in the spindle midzone region during anaphase and early telophase [85]. Thereafter, DNM2 is accumulated at the intracellular bridge where the final separation occurs. The time required for separation of the two daughter cells is longer in DNM2 knock-out cells [53]. Taken together, these data suggest that DNM2 may regulate microtubule-dependent processes by acting on microtubule dynamics and organisation.

6. $\underline{\text { Apoptosis}}$. In order to establish a stable Hela cell line over-expressing DNM2 isoform 2, Fish et al. have reported a significant cell toxicity in dividing cells [86]. The cytotoxicity occurred via induction of apoptosis by a p53-dependent mechanism. Similar results were gained in vascular smooth muscle cells [87]. The capacity to trigger apoptosis appears DNM2-specific as DNM1 over-expression does not induce apoptosis [86]. The GTPase domain of DNM2 is crucial to induce apoptosis [88]. Besides, a point mutation (p.I684K) in the DNM2 GED enhances the apoptosis induction by the wild-type DNM2 suggesting that GED negatively regulates this DNM2 function [88]. Mitochondria are key actors in apoptosis and, interestingly, DNM2 has been detected in isolated mitochondria from bovine lymphoblastoid BL-3 cells [89]. However, to our knowledge, such localization has not been reported in other cell lines or tissues. DNM2 also regulates the apoptosis-inducing Fas-Fas 
ligand pathway by facilitating the transport of Fas from the trans-Golgi network to the plasma membrane [90].

7. Specific functions of DNM2 isoforms. In a cultured rat epithelial cell line (clone 9), both DNM2 isoforms 1 and 3 show punctuate labeling of clathrin heavy chain-positive or -negative structures, but only isoform 1, with the GEIL sequence in the middle domain, appears located to the Golgi apparatus [14]. These data suggest a role for the GEIL sequence in targeting to the Golgi apparatus. However, cell-type specificity probably exists, as isoforms without the GEIL sequence were also shown to be targeted to the Golgi apparatus in MDCK cells [56], 3T3L1 adipocytes [91] and fibroblastoid-like cells derived from mouse embryonic stem cells [53]. Nevertheless, this possible differential localization argues for distinct functions. Indeed, in clone 9 cells, the K44A mutants of isoforms 2 and 4 are able to inhibit fluid-phase endocytosis, whereas the mutant forms of isoforms 1 and 3 do not [52], and are more potent inhibitors of clathrin-mediated endocytosis. Similarly in a hepatocyte cell line, the K44Aisoform 1 inhibits caveolae-dependent internalization, but not the other K44A mutant isoforms [92]. In fibroblastoid-like cells derived from mouse embryonic stem cells, isoforms 2 and 4 are the most efficient at rescuing export from the Golgi in DNM2 knock-out cells [53]. Altogether, these data suggest a preferential involvement of isoforms 1 and 3 in clathrinand caveolae-dependent endocytosis, whereas isoforms 2 and 4 participate in uncoated endocytosis and trafficking from the Golgi apparatus. However, cell-type specificity also occurs as the four isoforms exhibit a similar subcellular distribution in 3T3L1 adipocytes and dominant negative mutants of each isoform similarly affect basal and insulin-stimulated GLUT4 trafficking [91].

\section{DNM2 and human disease}


Mutations in the DNM2 gene cause rare forms of the Charcot-Marie-Tooth peripheral neuropathy (CMT) [2, 93-96] and autosomal dominant centronuclear myopathy (CNM) [3, 15, 97-99]. The 19 reported heterozygous mutations affect only the Middle domain, the PH domain and the GED (figure 1B). DNM2-related CNM is a slowly progressive congenital myopathy characterized by frequent centrally located nuclei in muscle fibers. The most common clinical features are delayed motor milestones, facial and generalized muscle weakness, ptosis and ophthalmoplegia [100]. Nevertheless, the severity of DNM2-CNM is variable, ranging from severe neonatal to mild late-onset forms. DNM2-CMT is a peripheral neuropathy characterized by progressive muscle weakness and atrophy. DNM2 mutations can cause axonal CMT (CMT2) and dominant intermediate CMT (DI-CMT-B). In CMT2, the nerve conduction velocity is usually normal (> $38 \mathrm{~m} / \mathrm{s}$ for the median nerve, which represents the cut-off value between the demyelinating CMT1 and the axonal CMT2). In the group of rare patients affected by DI-CMT-B, the nerve conduction velocity values are intermediate (between 25 and $45 \mathrm{~m} / \mathrm{s}$ ). In some CMT patients, neuropathy is associated with neutropenia [2, 94, 96] but this association has not been described in DNM2-CNM patients. Clinical overlap could exist in some patients, but the majority of patients are affected by a tissuespecific disorder targeting either skeletal muscle or peripheral nerve [94, 99, 100]. Among the 19 distinct DNM2 mutations identified to date, there are no mutations common to the two disorders and no mutations in the regions of variation due to alternative splicing. No clear genotype-phenotype relationship can be generated, except for the de novo mutations located in the C-terminal part of the PH domain, which are all associated with a severe neonatal CNM phenotype [98]. In these patients, the phenotype progressively improves, suggesting compensatory mechanisms. Of note is that the CMT-mutation G358R, is located in the 
cathepsin L cleavage site [29] and therefore may impair the regulation of DNM2 by proteolysis.

More recently, the DNM2 gene has been described as a susceptibility gene for lateonset Alzheimer disease [101], and DNM2 expression was subsequently found to be decreased in the brains of late-onset Alzheimer patients [102]. Cognitive impairments have been reported in some CNM patients harboring the p.E368Q [97], p.R465W [103; Family 1] and p.R369Q [103; Families 2 and 3] DNM2 mutations. Future studies will be necessary to determine the prevalence of central nervous system involvement in DNM2-related diseases.

\section{Pathophysiological hypotheses}

1. Membrane trafficking and signaling pathway hypothesis. In addition to the DNM2 mutations in autosomal dominant CNM, mutations in the BIN1 gene encoding amphiphysin 2, a partner of DNM2 in the endocytic process, can cause the autosomal recessive form of the disease [104]. This suggests that endocytic impairment is implicated in the pathophysiological mechanisms of autosomal CNM. Indeed, impairment of clathrin-mediated endocytosis was also reported in cultured cells expressing CNM- or CMT-DNM2 mutants [2, 15, 83]. The crucial question which remains to be explored is how a defect in clathrin-mediated endocytosis can alter the cell function. Endocytosis (via clathrin-coated vesicles, caveolae or uncoated vesicles) regulates fundamental processes including nutrient uptake, membrane composition and turnover, cell adhesion or migration, pathogen entry, and signaling of $G$ protein-coupled receptors, tyrosine kinase receptors or channels [105-107]. Thus, DNM2 mutations may have a large spectrum of functional consequences. On one hand, DNM2 mutations may lead to a decrease in receptor stimulated signaling as shown for the MAPK ERK1/2 pathway $[15,108]$. On the other hand, DNM2 mutations may lead to a prolonged 
half-life of various proteins at the cell surface due to a defect in protein removal, similar to that as suggested for the EnaC sodium channel [109, 110], KCNQ1 potassium channel subunits [111] or the GLUT4 glucose transporter [91, 112-114]. A deregulation of glucose transport in patients with DNM2 mutations could have a strong impact on muscle fibers given their high glucose consumption. Of note, the microtubule network plays an important role in GLUT4 trafficking [115] and a decrease in muscle weight has been reported for a transgenic mouse over-expressing GLUT4 [116].

To date, the impact of disease-associated DNM2 mutants on other membrane trafficking processes in which DNM2 is involved, especially in endosomal and Golgi pathways, has not been studied. In cells over-expressing the K44A-DNM2 mutant, an impairment in the trafficking from the Golgi apparatus has been reported $[117,118]$. We cannot exclude a participation of these pathways in the pathomechanisms of DNM2-related disorders.

2. Cytoskeleton. In DNM2-CNM, the majority of patients harbour a mutation in the middle domain, which is essential for the centrosomal localization of DNM2 and for its interaction with $\gamma$-tubulin [84]. Previous results in skin fibroblasts indicate that transfected GFP-DNM2mutants failed to be correctly targeted to the centrosome, suggesting that DNM2 mutations might cause CNM by interfering with centrosome function [3]. In addition, CMT-related DNM2 mutants can disorganize the microtubule cytoskeleton [2] and one particular CMTmutant was shown to impair microtubule-dependent membrane transport [83]. During skeletal muscle differentiation a profound reorganization of the microtubule network occurs, changing from a classical network centered on the juxtanuclear centrosome in myoblasts, to a longitudinal organization along the axis of differentiated myotubes [119]. One can hypothesize that mutated-DNM2 can impair functions associated with this specific 
cytoskeleton reorganization. In addition to their roles in intracellular trafficking, the microtubule and actin networks regulate cellular architecture including nuclear positioning $[120,121]$. Thus, cytoskeletal impairment may be implicated in the abnormal central location of the nuclei in the muscle fibers in CNM. In CMT, DNM2 mutations could also induce a destabilization of the microtubule network leading to abnormal axonal transport and protein trafficking, a pathophysiological mechanism described previously in various forms of CMT [122].

\section{Concluding remarks and open questions}

Given the numerous distinct functions in which the ubiquitously expressed DNM2 is involved, the identification of pathophysiological mechanisms will be a challenge. The phenotypes encountered in CNM and CMT patients are probably due to impairment of the various functions of the protein. DNM2 is engaged in numerous protein-protein interactions (Table 1) but the relevance of these interactions in skeletal muscle and the nervous system, is largely unexplored. For example, DNM2 interacts with $\beta$-catenin in rat testis in relation to the maintenance of the blood-testis barrier integrity [123] but no data are available on this interaction in skeletal muscle where $\beta$-catenin plays an important role [124, 125]. Another essential unresolved question is whether each particular mutation can similarly affect the functions of the four DNM2 isoforms. Finally, whereas some data emerge on the impact of disease-related DNM2 mutations on the microtubule network, their impact on the actin cytoskeleton is totally unknown. Future developments and characterization of animal models will certainly be useful to better determine the main functions of DNM2 in vivo, especially in skeletal muscle and peripheral nerves where membrane trafficking displays different characteristics depending to the length of the cells. 
16. Durieux

\section{Acknowledgements}

We thank Dr Rachel Peat and Dr Edgar Gomes for helpful advices. Anne-Cécile Durieux was a recipient of fellowship from the Association Française contre les Myopathies (AFM). 


\section{Abbreviations}

PI4,5P2: phophatidylinositol 4,5-bisphosphate

PI3,4,5P3: phophatidylinositol 3,4,5-triphosphate

PI3,4P2: phophatidylinositol 3,4-bisphosphate

PI4P: phophatidylinositol 4-monophosphate

PI3P: phophatidylinositol 3-monophosphate

LPA: lysophosphatidic acid

GLUT4: glucose transporter 4

TGN: Trans-Golgi network

BAR: Bin1/Amphiphysin/RVS167 
18. Durieux

\section{Legends}

\section{Figure 1: DNM2 gene organization and mutations.}

A. Schematic organization of the human DNM2 gene showing alternative splicing. Asterisks indicate the seven exons in which disease associated mutations have been identified. Exons were colored relative to the encoded protein domain illustrated in $\mathrm{B}$. The combination of the two alternative splice sites leads to the translation of four DNM2 isoforms. B. Schematic representation of DNM2 showing the five protein domains and the position of the 19 diseaseassociated mutations. CMT-mutations are indicated in green and CNM-mutations in red. The two regions of variation (at positions 399-445 and 516-519) between the four isoforms were indicated in the middle domain by black lines. In black are indicated the sites of posttranslational modifications (phosphorylation, nitrosylation and cathepsin L cleavage). In blue are indicated the DNM2 constructs with point mutations or small deletions overexpressed in vitro $[2,15,29,79,83,88,126,159]$.

\section{Figure 2: DNM2 cellular functions}

Representation of the multiple cellular localizations reported for DNM2 (in red). EE: early endosome. LE: late endosome. 


\section{References}

1. Heymann JA, Hinshaw JE (2009) Dynamins at a glance. J Cell Sci 122: 3427-3431.

2. Zuchner S, Noureddine $M$, Kennerson M, Verhoeven K, Claeys K, De Jonghe P, Merory J, Oliveira SA, Speer MC, Stenger JE, Walizada G, Zhu D, Pericak-Vance MA, Nicholson G, Timmerman V, Vance JM (2005) Mutations in the pleckstrin homology domain of dynamin 2 cause dominant intermediate Charcot-Marie-Tooth disease. Nat Genet 37: 289294

3. Bitoun M, Maugenre S, Jeannet PY, Lacène E, Ferrer X, Laforêt P, Martin JJ, Laporte J, Lochmuller H, Beggs AH, Fardeau M, Eymard B, Romero NB, Guicheney P (2005) Mutations in dynamin 2 cause dominant Centronuclear Myopathy. Nature Genet 37: 12071209

4. Shpetner HS, Vallee RB (1989) Identification of dynamin, a novel mechanochemical enzyme that mediates interactions between microtubules. Cell 59: 421-432

5. Sontag JM, Fykse EM, Ushkaryov Y, Liu JP, Robinson PJ, Sudhof TC (1994) Differential expression and regulation of multiple dynamins. J Biol Chem 269: 4547-4554

6. Lin HC, Barylko B, Achiriloaie M, Albanesi JP (1997) Phosphatidylinositol (4,5)bisphosphate-dependent activation of dynamins I and II lacking the proline/arginine-rich domains. J Biol Chem 272: 25999-26004

7. Rappoport JZ, Simon SM (2003) Real-time analysis of clathrin-mediated endocytosis during cell migration. J Cell Science 116: 847-855

8. Fourgeaud L, Bessis AS, Rossignol F, Pin JP, Olivo-Marin JC, Hemar A (2003) The metabotropic glutamate receptor mGluR5 is endocytosed by a clathrin-independent pathway. J Biol Chem 278: 12222-12230

9. Kabbani N, Jeromin A, Levenson R (2004) Dynamin-2 associates with the dopamine receptor signalplex and regulates internalization of activated D2 receptors. Cell Signalling 16: 497-503

10. Artalejo CR, Elhamdani A, Palfrey HC (2002) Sustained stimulation shifts the mechanism of endocytosis from dynamin-1-dependent rapid endocytosis to clathrin- and dynamin-2-mediated slow endocytosis in chromaffin cells. Proc Natl Acad Sci U S A 99: 6358-6363

11. Elhamdani A, Azizi F, Solomaha E, Palfrey HC, Artalejo CR (2006) Two mechanistically distinct forms of endocytosis in adrenal chromaffin cells: Differential effects of SH3 domains and amphiphysin antagonism. FEBS Lett 580: 3263-3269

12. Cook TA, Urrutia R, McNiven MA (1994) Identification of dynamin 2, an isoform ubiquitously expressed in rat tissues. Proc Natl Acad Sci U S A 91: 644-648

13. Diatloff-Zito C, Gordon AJ, Duchaud E, Merlin G (1995) Isolation of an ubiquitously expressed cDNA encoding human dynamin II, a member of the large GTP-binding protein family. Gene 163: 301-306

14. Cao H, Garcia F, McNiven MA (1998) Differential distribution of dynamin isoforms in mammalian cells. Mol Biol Cell 9: 2595-2609

15. Bitoun M, Durieux AC, Prudhon B, Bevilacqua JA, Herledan A, Sakanyan V, Urtizberea A, Cartier L, Romero NB, Guicheney P (2009) Dynamin 2 mutations associated with human diseases impair clathrin-mediated receptor endocytosis. Hum Mutat 30: 14191427

16. Smirnova E, Shurland DL, Newman-Smith ED, Pishvaee B, van der Bliek AM (1999) A model for dynamin self-assembly based on binding between three different protein domains. J Biol Chem 274: 14942-14947 
17. Chen YJ, Zhang P, Egelman EH, Hinshaw JE (2004) The stalk region of dynamin drives the constriction of dynamin tubes. Nat Struct Mol Biol 11: 574-575

18. Dong J, Misselwitz R, Welfle H, Westermann P (2000) Expression and purification of dynamin II domains and initial studies on structure and function. Protein Expr Purif 20: 314323

19. Klein DE, Lee A, Frank DW, Marks MS, Lemmon MA (1998) The pleckstrin homology domains of dynamin isoforms require oligomerization for high affinity phosphoinositide binding. J Biol Chem 273: 27725-27733

20. Sever S, Muhlberg AB, Schmid SL (1999) Impairment of dynamin's GAP domain stimulates receptor-mediated endocytosis. Nature 398: 481-486

21. Warnock DE, Baba T, Schmid SL (1997) Ubiquitously expressed dynamin-II has a higher intrinsic GTPase activity and a greater propensity for self-assembly than neuronal dynamin-I. Mol Biol Cell 8: 2553-2562

22. Eccleston JF, Binns DD, Davis CT, Albanesi JP, Jameson DM (2002) Oligomerization and kinetic mechanism of the dynamin GTPase. Eur Biophys J 31: 275-282

23. Soulet F, Yarar D, Leonard M, Schmid SL (2005) SNX9 regulates dynamin assembly and is required for efficient clathrin-mediated endocytosis. Mol Biol Cell 16: 2058-2067

24. Solomaha E, Palfrey HC (2005) Conformational changes in dynamin on GTP binding and oligomerization reported by intrinsic and extrinsic fluorescence. Biochem J 391: 601-611.

25. Shajahan AN, Timblin BK, Sandoval R, Tiruppathi C, Malik AB, Minshall RD (2004) Role of Src-induced dynamin-2 phosphorylation in caveolae-mediated endocytosis in endothelial cells. J Biol Chem 279: 20392-20400

26. Gorska MM, Cen O, Liang Q, Stafford SJ, Alam R (2006) Differential regulation of interleukin 5-stimulated signaling pathways by dynamin. J Biol Chem 281: 14429-14439

27. Efendiev R, Yudowski GA, Zwiller J, Leibiger B, Katz AI, Berggren PO, Pedemonte $\mathrm{CH}$, Leibiger IB, Bertorello AM (2002) Relevance of dopamine signals anchoring dynamin-2 to the plasma membrane during $\mathrm{Na}+, \mathrm{K}+$-ATPase endocytosis. J Biol Chem 277: 44108-44114 28. Kang-Decker N, Cao S, Chatterjee S, Yao J, Egan LJ, Semela D, Mukhopadhyay D, Shah V (2007) Nitric oxide promotes endothelial cell survival signaling through Snitrosylation and activation of dynamin-2. J Cell Sci 120: 492-501

29. Sever S, Altintas MM, Nankoe SR, Moller CC, Ko D, Wei C, Henderson J, del Re EC, Hsing L, Erickson A, Cohen CD, Kretzler M, Kerjaschki D, Rudensky A, Nikolic B, Reiser J (2007) Proteolytic processing of dynamin by cytoplasmic cathepsin L is a mechanism for proteinuric kidney disease. J Clin Invest 117: 2095-2104

30. Liu JP, Zhang QX, Baldwin G, Robinson PJ (1996) Calcium binds dynamin I and inhibits its GTPase activity. J Neurochem 66: 2074-2081

31. Cousin MA, Robinson PJ (2000) $\mathrm{Ca}(2+)$ influx inhibits dynamin and arrests synaptic vesicle endocytosis at the active zone. J Neurosci 20: 949-957

32. Cook TA, Mesa KJ, Gebelein BA, Urrutia RA (1996) Upregulation of dynamin II expression during the acquisition of a mature pancreatic acinar cell phenotype. J Histochem Cytochem 44: 1373-1378

33. Cook T, Mesa K, Urrutia R (1996) Three dynamin-encoding genes are differentially expressed in developing rat brain. J Neurochem 67: 927-931

34. Zhang Q, Purohit V, Yoburn BC (2005) Continuous opioid agonist treatment dosedependently regulates mu-opioid receptors and dynamin-2 in mouse spinal cord. Synapse 56: 123-128

35. Yoburn BC, Purohit V, Patel K, Zhang Q (2004) Opioid agonist and antagonist treatment differentially regulates immunoreactive mu-opioid receptors and dynamin-2 in vivo. Eur J Pharmacol 498: 87-96 
36. Rajashekara V, Patel CN, Patel K, Purohit V, Yoburn BC (2003) Chronic opioid antagonist treatment dose-dependently regulates mu-opioid receptors and trafficking proteins in vivo. Pharmacol Biochem Behav 75: 909-913

37. Schroeder JA, McCafferty MR, Unterwald EM (2009) Regulation of dynamin 2 and G protein-coupled receptor kinase 2 in rat nucleus accumbens during acute and repeated cocaine administration. Synapse 63: 863-870

38. Lundmark R, Carlsson SR (2003) Sorting Nexin 9 Participates in Clathrin-mediated Endocytosis through Interactions with the Core Components. J Biol Chem 278: 46772-46781

39. Lundmark R, Carlsson SR (2004) Regulated membrane recruitment of dynamin-2 mediated by sorting nexin 9. J Biol Chem 279: 42694-42702

40. Lundmark R, Carlsson SR (2005) Expression and properties of sorting nexin 9 in dynamin-mediated endocytosis. Methods Enzymol 404: 545-556

41. Zoncu R, Perera RM, Sebastian R, Nakatsu F, Chen H, Balla T, Ayala G, Toomre D, De Camilli PV (2007) Loss of endocytic clathrin-coated pits upon acute depletion of phosphatidylinositol 4,5-bisphosphate. Proc Natl Acad Sci U S A 104: 3793-3798

42. Loerke D, Mettlen M, Yarar D, Jaqaman K, Jaqaman H, Danuser G, Schmid SL (2009) Cargo and dynamin regulate clathrin-coated pit maturation. PLoS Biol 7: e57

43. Gold ES, Underhill DM, Morrissette NS, Guo J, McNiven MA, Aderem A (1999) Dynamin 2 is required for phagocytosis in macrophages. J Exp Med 190: 1849-1856

44. Otsuka A, Abe T, Watanabe M, Yagisawa H, Takei K, Yamada H (2009) Dynamin 2 is required for actin assembly in phagocytosis in Sertoli cells. Biochem Biophys Res Commun 378: $478-482$

45. Henley JR, Krueger EW, Oswald BJ, McNiven MA (1998) Dynamin-mediated internalization of caveolae. J Cell Biol 141: 85-99

46. Oh P, McIntosh DP, Schnitzer JE (1998) Dynamin at the neck of caveolae mediates their budding to form transport vesicles by GTP-driven fission from the plasma membrane of endothelium. J Cell Biol 141: 101-114

47. Predescu SA, Predescu DN, Timblin BK, Stan RV, Malik AB (2003) Intersectin regulates fission and internalization of caveolae in endothelial cells. Mol Biol Cell 14: 49975010

48. Cao S, Yao J, McCabe TJ, Yao Q, Katusic ZS, Sessa WC, Shah V (2001) Direct interaction between endothelial nitric-oxide synthase and dynamin-2. Implications for nitricoxide synthase function. J Biol Chem 276: 14249-14256

49. Chatterjee S, Cao S, Peterson TE, Simari RD, Shah V (2003) Inhibition of GTPdependent vesicle trafficking impairs internalization of plasmalemmal eNOS and cellular nitric oxide production. J Cell Sci 116: 3645-3655

50. Maniatis NA, Brovkovych V, Allen SE, John TA, Shajahan AN, Tiruppathi C, Vogel SM, Skidgel RA, Malik AB, Minshall RD (2006) Novel mechanism of endothelial nitric oxide synthase activation mediated by caveolae internalization in endothelial cells. Circ Res 99: 870-877

51. Sanchez FA, Rana R, Kim DD, Iwahashi T, Zheng R, Lal BK, Gordon DM, Meininger CJ, Duran WN (2009) Internalization of eNOS and NO delivery to subcellular targets determine agonist-induced hyperpermeability. Proc Natl Acad Sci U S A 106: 6849-6853

52. Cao H, Chen J, Awoniyi M, Henley JR, McNiven MA (2007) Dynamin 2 mediates fluid-phase micropinocytosis in epithelial cells. J Cell Sci 120: 4167-4177

53. Liu YW, Surka MC, Schroeter T, Lukiyanchuk V, Schmid SL (2008) Isoform and splice-variant specific functions of dynamin-2 revealed by analysis of conditional knock-out cells. Mol Biol Cell 19: 5347-5359

54. Maier O, Knoblich M, Westermann P (1996) Dynamin II binds to the trans-Golgi network. Biochem Biophys Res Commun 223: 229-233 
55. Jones SM, Howell KE, Henley JR, Cao H, McNiven MA (1998) Role of dynamin in the formation of transport vesicles from the trans-Golgi network. Science 279: 573-577

56. Kreitzer G, Marmorstein A, Okamoto P, Vallee R, Rodriguez-Boulan E (2000) Kinesin and dynamin are required for post-Golgi transport of a plasma-membrane protein. Nat Cell Biol 2: 125-127

57. Yang Z, Li H, Chai Z, Fullerton MJ, Cao Y, Toh BH, Funder JW, Liu JP (2001) Dynamin II regulates hormone secretion in neuroendocrine cells. J Biol Chem 276: 42514260

58. Cao H, Weller S, Orth JD, Chen J, Huang B, Chen JL, Stamnes M, McNiven MA (2005) Actin and Arf1-dependent recruitment of a cortactin-dynamin complex to the Golgi regulates post-Golgi transport. Nat Cell Biol 7: 483-492

59. Kessels MM, Dong J, Leibig W, Westermann P, Qualmann B (2006) Complexes of syndapin II with dynamin II promote vesicle formation at the trans-Golgi network. J Cell Sci 119: $1504-1516$

60. van Dam EM, Stoorvogel W (2002) Dynamin-dependent transferrin receptor recycling by endosome-derived clathrin-coated vesicles. Mol Biol Cell 13: 169-182

61. Nicoziani P, Vilhardt F, Llorente A, Hilout L, Courtoy PJ, Sandvig K, van Deurs B (2000) Role for dynamin in late endosome dynamics and trafficking of the cation-independent mannose 6-phosphate receptor. Mol Biol Cell 11: 481-495

62. Galas MC, Chasserot-Golaz S, Dirrig-Grosch S, Bader MF (2000) Presence of dynamin--syntaxin complexes associated with secretory granules in adrenal chromaffin cells. J Neurochem 75: 1511-1519

63. Zhao L, Shi X, Li L, Miller DJ (2007) Dynamin 2 associates with complexins and is found in the acrosomal region of mammalian sperm. Mol Reprod Dev 74: 750-757

64. Min L, Leung YM, Tomas A, Watson RT, Gaisano HY, Halban PA, Pessin JE, Hou JC (2007) Dynamin is functionally coupled to insulin granule exocytosis. J Biol Chem 282: 33530-33536

65. Arneson LN, Segovis CM, Gomez TS, Schoon RA, Dick CJ, Lou Z, Billadeau DD, Leibson PJ (2008) Dynamin 2 regulates granule exocytosis during NK cell-mediated cytotoxicity. J Immunol 181: 6995-7001

66. Di A, Nelson DJ, Bindokas V, Brown ME, Libunao F, Palfrey HC (2003) Dynamin regulates focal exocytosis in phagocytosing macrophages. Mol Biol Cell 14: 2016-2028

67. Jaiswal JK, Rivera VM, Simon SM (2009) Exocytosis of post-Golgi vesicles is regulated by components of the endocytic machinery. Cell 137: 1308-1319

68. Kessels MM, Engqvist-Goldstein AE, Drubin DG, Qualmann B (2001) Mammalian Abp1, a signal-responsive F-actin-binding protein, links the actin cytoskeleton to endocytosis via the GTPase dynamin. J Cell Biol 153: 351-366

69. McNiven MA, Kim L, Krueger EW, Orth JD, Cao H, Wong TW (2000) Regulated interactions between dynamin and the actin-binding protein cortactin modulate cell shape. $\mathrm{J}$ Cell Biol 151: 187-198

70. Schafer DA, Weed SA, Binns D, Karginov AV, Parsons JT, Cooper JA (2002) Dynamin2 and Cortactin Regulate Actin Assembly and Filament Organization. Curr Biol 12: 1852-1857

71. Cao H, Orth JD, Chen J, Weller SG, Heuser JE, McNiven MA (2003) Cortactin is a component of clathrin-coated pits and participates in receptor-mediated endocytosis. Mol Cell Biol 23: 2162-2170

72. Orth JD, Krueger EW, Cao H, McNiven MA (2002) The large GTPase dynamin regulates actin comet formation and movement in living cells. Proc Natl Acad Sci U S A 99: $167-172$ 
73. Lee E, De Camilli P (2002) Dynamin at actin tails. Proc Natl Acad Sci U S A 99: 161166

74. Mooren OL, Kotova TI, Moore AJ, Schafer DA (2009) Dynamin2 GTPase and cortactin remodel actin filaments. J Biol Chem 284: 23995-24005

75. Krueger EW, Orth JD, Cao H, McNiven MA (2003) A Dynamin-Cortactin-Arp2/3 Complex Mediates Actin Reorganization in Growth Factor-stimulated Cells. Mol Biol Cell 14: 1085-1096

76. Schlunck G, Damke H, Kiosses WB, Rusk N, Symons MH, Waterman-Storer CM, Schmid SL, Schwartz MA (2004) Modulation of Rac localization and function by dynamin. Mol Biol Cell 15: 256-267

77. Ezratty EJ, Partridge MA, Gundersen GG (2005) Microtubule-induced focal adhesion disassembly is mediated by dynamin and focal adhesion kinase. Nat Cell Biol 7: 581-590

78. Vassilieva EV, Gerner-Smidt K, Ivanov AI, Nusrat A (2008) Lipid rafts mediate internalization of beta1-integrin in migrating intestinal epithelial cells. Am J Physiol Gastrointest Liver Physiol 295: G965-976

79. Ochoa GC, Slepnev VI, Neff L, Ringstad N, Takei K, Daniell L, Kim W, Cao H, McNiven M, Baron et a (2000) A functional link between dynamin and the actin cytoskeleton at podosomes. J Cell Biol 150: 377-389

80. Baldassarre M, Pompeo A, Beznoussenko G, Castaldi C, Cortellino S, McNiven MA, Luini A, Buccione R (2003) Dynamin participates in focal extracellular matrix degradation by invasive cells. Mol Biol Cell 14: 1074-1084

81. Yoo J, Jeong MJ, Cho HJ, Oh ES, Han MY (2005) Dynamin II interacts with syndecan-4, a regulator of focal adhesion and stress-fiber formation. Biochem Biophys Res Commun 328: 424-431

82. Hamao K, Morita M, Hosoya H (2009) New function of the proline rich domain in dynamin-2 to negatively regulate its interaction with microtubules in mammalian cells. Exp Cell Res 315: 1336-1345

83. Tanabe K, Takei K (2009) Dynamic instability of microtubules requires dynamin 2 and is impaired in a Charcot-Marie-Tooth mutant. J Cell Biol 185: 939-948

84. Thompson HM, Cao H, Chen J, Euteneuer U, McNiven MA (2004) Dynamin 2 binds gamma-tubulin and participates in centrosome cohesion. Nat Cell Biol 6: 335-342

85. Thompson HM, Skop AR, Euteneuer U, Meyer BJ, McNiven MA (2002) The large GTPase dynamin associates with the spindle midzone and is required for cytokinesis. Curr Biol 12: 2111-2117

86. Fish KN, Schmid SL, Damke H (2000) Evidence that dynamin-2 functions as a signaltransducing GTPase. J Cell Biol 150: 145-154

87. Kashiwakura Y, Watanabe M, Kusumi N, Sumiyoshi K, Nasu Y, Yamada H, Sawamura T, Kumon H, Takei K, Daida H (2004) Dynamin-2 regulates oxidized low-density lipoprotein-induced apoptosis of vascular smooth muscle cell. Circulation 110: 3329-3334

88. Soulet F, Schmid SL, Damke H (2006) Domain requirements for an endocytosisindependent, isoform-specific function of dynamin-2. Exp Cell Res 312: 3539-3545

89. Atapattu DN, Albrecht RM, McClenahan DJ, Czuprynski CJ (2008) Dynamin-2dependent targeting of mannheimia haemolytica leukotoxin to mitochondrial cyclophilin D in bovine lymphoblastoid cells. Infect Immun 76: 5357-5365

90. Ivanov VN, Ronai Z, Hei TK (2006) Opposite roles of FAP-1 and dynamin in the regulation of Fas (CD95) translocation to the cell surface and susceptibility to Fas ligandmediated apoptosis. J Biol Chem 281: 1840-1852

91. Kao AW, Yang C, Pessin JE (2000) Functional comparison of the role of dynamin 2 splice variants on GLUT-4 endocytosis in 3T3L1 adipocytes. Am J Physiol Endocrinol Metabol 278: E825-E831 
92. Yao Q, Chen J, Cao H, Orth JD, McCaffery JM, Stan RV, McNiven MA (2005) Caveolin-1 interacts directly with dynamin-2. J Mol Biol 348: 491-501

93. Fabrizi GM, Ferrarini M, Cavallaro T, Cabrini I, Cerini R, Bertolasi L, Rizzuto N (2007) Two novel mutations in dynamin-2 cause axonal Charcot-Marie-Tooth disease. Neurology 69: 291-295

94. Bitoun M, Stojkovic T, Prudhon B, Maurage CA, Latour P, Vermersch P, Guicheney $\mathrm{P}$ (2008) A novel mutation in the dynamin 2 gene in a Charcot-Marie-Tooth type 2 patient: Clinical and pathological findings. Neuromuscul Disord 18: 334-338

95. Gallardo E, Claeys KG, Nelis E, Garcia A, Canga A, Combarros O, Timmerman V, De Jonghe P, Berciano J (2008) Magnetic resonance imaging findings of leg musculature in Charcot-Marie-Tooth disease type 2 due to dynamin 2 mutation. J Neurol 255: 986-992

96. Claeys KG, Zuchner S, Kennerson M, Berciano J, Garcia A, Verhoeven K, Storey E, Merory JR, Bienfait HM, Lammens M, Nelis E, Baets J, De Vriendt E, Berneman ZN, De Veuster I, Vance JM, Nicholson G, Timmerman V, De Jonghe P (2009) Phenotypic spectrum of dynamin 2 mutations in Charcot-Marie-Tooth neuropathy. Brain 132: 1741-1752

97. Echaniz-Laguna A, Nicot AS, Carre S, Franques J, Tranchant C, Dondaine N, Biancalana V, Mandel JL, Laporte J (2007) Subtle central and peripheral nervous system abnormalities in a family with centronuclear myopathy and a novel dynamin 2 gene mutation. Neuromuscul Disord 17: 955-959

98. Bitoun M, Bevilacqua JA, Prudhon B, Maugenre S, Taratuto AL, Monges S, Lubieniecki F, Cances C, Uro-Coste E, Mayer M, Fardeau M, Romero NB, Guicheney P (2007) Dynamin 2 mutations cause sporadic centronuclear myopathy with neonatal onset. Ann Neurol 62: 666-670

99. Bitoun M, Bevilacqua JA, Eymard B, Prudhon B, Fardeau M, Guicheney P, Romero NB (2009) A new centronuclear myopathy phenotype due to a novel dynamin 2 mutation. Neurology 72: 93-95

100. Fischer D, Herasse M, Bitoun M, Barragán-Campos HM, Chiras J, Laforêt P, Fardeau M, Eymard B, Guicheney P, Romero NB (2006) Characterization of the muscle involvement in dynamin 2- related centronuclear myopathy. Brain 129: 1463-1469

101. Aidaralieva NJ, Kamino K, Kimura R, Yamamoto M, Morihara T, Kazui H, Hashimoto R, Tanaka T, Kudo T, Kida T, Okuda J, Uema T, Yamagata H, Miki T, Akatsu H, Kosaka K, Takeda M (2008) Dynamin 2 gene is a novel susceptibility gene for late-onset Alzheimer disease in non-APOE-epsilon4 carriers. J Hum Genet 53: 296-302

102. Kamagata E, Kudo T, Kimura R, Tanimukai H, Morihara T, Sadik MG, Kamino K, Takeda M (2009) Decrease of dynamin 2 levels in late-onset Alzheimer's disease alters Abeta metabolism. Biochem Biophys Res Commun 379: 691-695

103. Jeannet PY, Bassez G, Eymard B, Laforet P, Urtizberea JA, Rouche A, Guicheney P, Fardeau M, Romero NB (2004) Clinical and histologic findings in autosomal centronuclear myopathy. Neurology 62: 1484-1490

104. Nicot AS, Toussaint A, Tosch V, Kretz C, Wallgren-Pettersson C, Iwarsson E, Kingston H, Garnier JM, Biancalana V, Oldfors A, Mandel JL, Laporte J (2007) Mutations in amphiphysin 2 (BIN1) disrupt interaction with dynamin 2 and cause autosomal recessive centronuclear myopathy. Nat Genet 39: 1134-1139

105. Wolfe BL, Trejo J (2007) Clathrin-dependent mechanisms of G protein-coupled receptor endocytosis. Traffic 8: 462-470

106. Zeng WZ, Babich V, Ortega B, Quigley R, White SJ, Welling PA, Huang CL (2002) Evidence for endocytosis of ROMK potassium channel via clathrin-coated vesicles. Am J Physiol Renal Physiol 283: F630-639

107. Doherty GJ, McMahon HT (2009) Mechanisms of Endocytosis. Annu Rev Biochem 78: 857-902 
108. Kranenburg O, Verlaan I, Moolenaar WH (1999) Dynamin is required for the activation of mitogen-activated protein (MAP) kinase by MAP kinase kinase. J Biol Chem 274: 35301-35304

109. Shimkets RA, Lifton RP, Canessa CM (1997) The activity of the epithelial sodium channel is regulated by clathrin-mediated endocytosis. J Biol Chem 272: 25537-25541

110. Pochynyuk O, Staruschenko A, Bugaj V, Lagrange L, Stockand JD (2007) Quantifying RhoA facilitated trafficking of the epithelial $\mathrm{Na}+$ channel toward the plasma membrane with total internal reflection fluorescence-fluorescence recovery after photobleaching. J Biol Chem 282: 14576-14585

111. Xu X, Kanda VA, Choi E, Panaghie G, Roepke TK, Gaeta SA, Christini DJ, Lerner DJ, Abbott GW (2009) MinK-dependent internalization of the IKs potassium channel. Cardiovasc Res 82: 430-438

112. Volchuk A, Narine S, Foster LJ, Grabs D, De Camilli P, Klip A (1998) Perturbation of dynamin II with an amphiphysin SH3 domain increases GLUT4 glucose transporters at the plasma membrane in 3T3-L1 adipocytes. Dynamin II participates in GLUT4 endocytosis. J Biol Chem 273: 8169-8176

113. Omata W, Shibata H, Suzuki Y, Tanaka S, Suzuki T, Takata K, Kojima I (1997) Subcellular distribution of GLUT4 in Chinese hamster ovary cells overexpressing mutant dynamin: evidence that dynamin is a regulatory GTPase in GLUT4 endocytosis. Biochem Biophys Res Commun 241: 401-406

114. Antonescu CN, Diaz M, Femia G, Planas JV, Klip A (2008) Clathrin-dependent and independent endocytosis of glucose transporter 4 (GLUT4) in myoblasts: regulation by mitochondrial uncoupling. Traffic 9: 1173-1190

115. Olson AL, Eyster CA, Duggins QS, Knight JB (2003) Insulin promotes formation of polymerized microtubules by a phosphatidylinositol 3-kinase-independent, actin-dependent pathway in 3T3-L1 adipocytes. Endocrinology 144: 5030-5039

116. Tsao TS, Li J, Chang KS, Stenbit AE, Galuska D, Anderson JE, Zierath JR, McCarter RJ, Charron MJ (2001) Metabolic adaptations in skeletal muscle overexpressing GLUT4: effects on muscle and physical activity. FASEB J 15: 958-969

117. Altschuler Y, Barbas SM, Terlecky LJ, Tang K, Hardy S, Mostov KE, Schmid SL (1998) Redundant and distinct functions for dynamin-1 and dynamin-2 isoforms. J Cell Biol 143: $1871-1881$

118. Cao H, Thompson HM, Krueger EW, McNiven MA (2000) Disruption of Golgi structure and function in mammalian cells expressing a mutant dynamin. J Cell Science 113: 1993-2002

119. Tassin AM, Maro B, Bornens M (1985) Fate of microtubule-organizing centers during myogenesis in vitro. J Cell Biol 100: 35-46

120. Morris NR (2003) Nuclear positioning: the means is at the ends. Curr Opin Cell Biol 15: 54-59

121. Starr DA, Han M (2003) ANChors away: an actin based mechanism of nuclear positioning. J Cell Sci 116: 211-216

122. Shy ME (2004) Charcot-Marie-Tooth disease: an update. Curr Opin Neurol 17: 579585

123. Lie PP, Xia W, Wang CQ, Mruk DD, Yan HH, Wong CH, Lee WM, Cheng CY (2006) Dynamin II interacts with the cadherin- and occludin-based protein complexes at the blood-testis barrier in adult rat testes. J Endocrinol 191: 571-586

124. Armstrong DD, Wong VL, Esser KA (2006) Expression of beta-catenin is necessary for physiological growth of adult skeletal muscle. Am J Physiol Cell Physiol 291: C185-188 125. Perez-Ruiz A, Ono Y, Gnocchi VF, Zammit PS (2008) beta-Catenin promotes selfrenewal of skeletal-muscle satellite cells. J Cell Sci 121: 1373-1382 
126. Jeong MJ, Yoo J, Lee SS, Lee KI, Cho A, Kwon BM, Moon MJ, Park YM, Han MY (2001) Increased GTP-binding to dynamin II does not stimulate receptor-mediated endocytosis. Biochem Biophys Res Commun 283: 136-142

127. Onabajo OO, Seeley MK, Kale A, Qualmann B, Kessels M, Han J, Tan TH, Song W (2008) Actin-binding protein 1 regulates B cell receptor-mediated antigen processing and presentation in response to B cell receptor activation. J Immunol 180: 6685-6695

128. Nakanishi A, Abe T, Watanabe M, Takei K, Yamada H (2008) Dynamin 2 cooperates with amphiphysin 1 in phagocytosis in sertoli cells. Acta Med Okayama 62: 385-391

129. Kojima C, Hashimoto A, Yabuta I, Hirose M, Hashimoto S, Kanaho Y, Sumimoto H, Ikegami T, Sabe H (2004) Regulation of Bin1 SH3 domain binding by phosphoinositides. EMBO J 23: 4413-4422

130. Turpin E, Russo-Marie F, Dubois T, de Paillerets C, Alfsen A, Bomsel M (1998) In adrenocortical tissue, annexins II and VI are attached to clathrin coated vesicles in a calciumindependent manner. Biochim Biophys Acta 1402: 115-130

131. Lu HA, Sun TX, Matsuzaki T, Yi XH, Eswara J, Bouley R, McKee M, Brown D (2007) Heat shock protein 70 interacts with aquaporin-2 and regulates its trafficking. J Biol Chem 282: 28721-28732

132. Chowdhury S, Shepherd JD, Okuno H, Lyford G, Petralia RS, Plath N, Kuhl D, Huganir RL, Worley PF (2006) Arc/Arg3.1 interacts with the endocytic machinery to regulate AMPA receptor trafficking. Neuron 52: 445-459

133. Tosoni D, Cestra G (2009) CAP (Cbl associated protein) regulates receptor-mediated endocytosis. FEBS Lett 583: 293-300

134. Kim YN, Bertics PJ (2002) The endocytosis-linked protein dynamin associates with caveolin-1 and is tyrosine phosphorylated in response to the activation of a noninternalizing epidermal growth factor receptor mutant. Endocrinology 143: 1726-1731

135. Singleton PA, Salgia R, Moreno-Vinasco L, Moitra J, Sammani S, Mirzapoiazova T, Garcia JG (2007) CD44 regulates hepatocyte growth factor-mediated vascular integrity. Role of c-Met, Tiam1/Rac1, dynamin 2, and cortactin. J Biol Chem 282: 30643-30657

136. Bruzzaniti A, Neff L, Sanjay A, Horne WC, De Camilli P, Baron R (2005) Dynamin forms a Src kinase-sensitive complex with $\mathrm{Cbl}$ and regulates podosomes and osteoclast activity. Mol Biol Cell 16: 3301-3313

137. Hartig SM, Ishikura S, Hicklen RS, Feng Y, Blanchard EG, Voelker KA, Pichot CS, Grange RW, Raphael RM, Klip A, Corey SJ (2009) The F-BAR protein CIP4 promotes GLUT4 endocytosis through bidirectional interactions with N-WASp and Dynamin-2. J Cell Sci 122: 2283-2291

138. Okamoto PM, Herskovits JS, Vallee RB (1997) Role of the basic, proline-rich region of dynamin in Src homology 3 domain binding and endocytosis. J Biol Chem 272: 1162911635

139. Cao S, Yao J, Shah V (2003) The proline-rich domain of dynamin-2 is responsible for dynamin-dependent in vitro potentiation of endothelial nitric-oxide synthase activity via selective effects on reductase domain function. J Biol Chem 278: 5894-5901

140. Sengar AS, Wang W, Bishay J, Cohen S, Egan SE (1999) The EH and SH3 domain Ese proteins regulate endocytosis by linking to dynamin and Eps15. Embo J 18: 1159-1171

141. Kamioka Y, Fukuhara S, Sawa H, Nagashima K, Masuda M, Matsuda M, Mochizuki N (2004) A novel dynamin-associating molecule, formin-binding protein 17, induces tubular membrane invaginations and participates in endocytosis. J Biol Chem 279: 40091-40099

142. Tsujita K, Suetsugu S, Sasaki N, Furutani M, Oikawa T, Takenawa T (2006) Coordination between the actin cytoskeleton and membrane deformation by a novel membrane tubulation domain of PCH proteins is involved in endocytosis. J Cell Biol 172: 269-279 
143. Kharbanda S, Saleem A, Yuan Z, Emoto Y, Prasad KV, Kufe D (1995) Stimulation of human monocytes with macrophage colony-stimulating factor induces a Grb2-mediated association of the focal adhesion kinase pp125FAK and dynamin. Proc Natl Acad Sci U S A 92: 6132-6136

144. Yoon SY, Koh WS, Lee MK, Park YM, Han MY (1997) Dynamin II associates with Grb2 SH3 domain in Ras transformed NIH3T3 cells. Biochem Biophys Res Commun 234: 539-543

145. Xin X, Rabiner CA, Mains RE, Eipper BA (2009) Kalirin12 interacts with dynamin. BMC Neurosci 10: 61

146. Bhattacharya R, Kang-Decker N, Hughes DA, Mukherjee P, Shah V, McNiven MA, Mukhopadhyay D (2005) Regulatory role of dynamin-2 in VEGFR-2/KDR-mediated endothelial signaling. FASEB J 19: 1692-1694

147. Rasmussen RK, Rusak J, Price G, Robinson PJ, Simpson RJ, Dorow DS (1998) Mixed-lineage kinase 2-SH3 domain binds dynamin and greatly enhances activation of GTPase by phospholipid. Biochem J 335: 119-124

148. Krendel M, Osterweil EK, Mooseker MS (2007) Myosin 1E interacts with synaptojanin-1 and dynamin and is involved in endocytosis. FEBS Lett 581: 644-650

149. Pizzato M, Helander A, Popova E, Calistri A, Zamborlini A, Palu G, Gottlinger HG (2007) Dynamin 2 is required for the enhancement of HIV-1 infectivity by Nef. Proc Natl Acad Sci U S A 104: 6812-6817

150. Icking A, Matt S, Opitz N, Wiesenthal A, Muller-Esterl W, Schilling K (2005) NOSTRIN functions as a homotrimeric adaptor protein facilitating internalization of eNOS. J Cell Sci 118: 5059-5069

151. Wan KF, Sambi BS, Frame M, Tate R, Pyne NJ (2001) The inhibitory gamma subunit of the type 6 retinal cyclic guanosine monophosphate phosphodiesterase is a novel intermediate regulating $\mathrm{p} 42 / \mathrm{p} 44$ mitogen-activated protein kinase signaling in human embryonic kidney 293 cells. J Biol Chem 276: 37802-37808

152. Park JB, Lee CS, Lee HY, Kim IS, Lee BD, Jang IH, Jung YW, Oh YS, Han MY, Jensen ON, Roepstorff P, Suh PG, Ryu SH (2004) Regulation of phospholipase D2 by GTPdependent interaction with dynamin. Adv Enzyme Regul 44: 249-264

153. Okamoto PM, Gamby C, Wells D, Fallon J, Vallee RB (2001) Dynamin isoformspecific interaction with the shank/ProSAP scaffolding proteins of the postsynaptic density and actin cytoskeleton. J Biol Chem 276: 48458-48465

154. Bruzzaniti A, Neff L, Sandoval A, Du L, Horne WC, Baron R (2009) Dynamin reduces Pyk2 Y402 phosphorylation and SRC binding in osteoclasts. Mol Cell Biol 29: 36443656

155. Haberg K, Lundmark R, Carlsson SR (2008) SNX18 is an SNX9 paralog that acts as a membrane tubulator in AP-1-positive endosomal trafficking. J Cell Sci 121: 1495-1505

156. Rufer AC, Rumpf J, von Holleben M, Beer S, Rittinger K, Groemping Y (2009) Isoform-selective interaction of the adaptor protein Tks5/FISH with Sos1 and dynamins. J Mol Biol 390: 939-950

157. Bertelsen V, Breen K, Sandvig K, Stang E, Madshus IH (2007) The Cbl-interacting protein TULA inhibits dynamin-dependent endocytosis. Exp Cell Res 313: 1696-1709

158. Gomez TS, Hamann MJ, McCarney S, Savoy DN, Lubking CM, Heldebrant MP, Labno CM, McKean DJ, McNiven MA, Burkhardt JK, Billadeau DD (2005) Dynamin 2 regulates $\mathrm{T}$ cell activation by controlling actin polymerization at the immunological synapse. Nat Immunol 6: 261-270

159. Szaszak M, Gaborik Z, Turu G, McPherson PS, Clark AJL, Catt KJ, Hunyady L (2002) Role of the proline-rich domain of dynamin-2 and its interactions with Src homology 3 domains during endocytosis of the AT1 angiotensin receptor. J Biol Chem 277: 21650-21656 
Table 1: Direct or indirect interactions with DNM2

\begin{tabular}{|c|c|c|c|c|}
\hline Name & OMIM & $\begin{array}{c}\text { Site of } \\
\text { interaction } \\
\text { in DNM2 }\end{array}$ & Function & Reference \\
\hline Abp1 & 610106 & nd & Endocytosis-actin bridge & {$[68,127]$} \\
\hline Amphiphysin 1 & 600418 & PRD & Membrane trafficking & {$[18,128]$} \\
\hline Amphiphysin 2 & 601248 & PRD & Membrane trafficking & {$[18,129]$} \\
\hline Annexin VI & 114070 & nd & Membrane trafficking & {$[130]$} \\
\hline Aquaporin 2 & 107777 & nd & Aquaporin trafficking & [131] \\
\hline Arc & 612461 & $\mathrm{PH}$ & AMPA receptor trafficking & {$[132]$} \\
\hline CAP & 605264 & nd & Actin remodelling during endocytosis & [133] \\
\hline$\beta$-catenin & 116806 & nd & Blood-testis barrier integrity & [123] \\
\hline Caveolin-1 & 601047 & nd & endocytosis & {$[92,134,135]$} \\
\hline CBL & 165360 & nd & Actin remodelling during endocytosis & [136] \\
\hline CIP4 & 604504 & nd & GLUT4 trafficking & [137] \\
\hline Complexin I & 605032 & nd & Acrosome formation and/or exocytosis & [63] \\
\hline Complexin II & 605033 & nd & Acrosome formation and/or exocytosis & [63] \\
\hline cortactin & 164765 & PRD & Actin assembly - Endocytosis- & {$[69,70,135]$} \\
\hline C-Src & 124095 & PRD & Cell signalling and membrane trafficking & [138] \\
\hline eNOS & 163729 & nd & NO production - Cell signalling & {$[48,139]$} \\
\hline Ese1 & 602191 & PRD & Endocytosis & {$[140]$} \\
\hline FAK & 600758 & PRD & Focal adhesion disassembly & [77] \\
\hline FBP17 & 606191 & PRD & Actin reorganization during endocytosis & {$[141,142]$} \\
\hline Grb2 & 108355 & PRD & Receptor internalization and signalling & {$[138,143,144]$} \\
\hline IL-5R $\alpha$ & 147851 & nd & IL-5 signaling pathway and trafficking & {$[26]$} \\
\hline Jak2 & 147796 & nd & IL-5 signaling pathway & {$[26]$} \\
\hline JAM-A & 605721 & nd & Blood-testis barrier integrity & [123] \\
\hline Kalirin 12 & 604605 & GTPase & Membrane trafficking & {$[145]$} \\
\hline KDR & 191306 & nd & Receptor signaling and expression & {$[146]$} \\
\hline LYN & 165120 & PRD & IL-5 signaling pathway & {$[26,138]$} \\
\hline MLK2 & 600137 & PRD & Actin (filipodia and membrane ruffles) & {$[147]$} \\
\hline Myosin 1E & 601479 & PRD & Receptor-mediated endocytosis & [148] \\
\hline $\mathrm{N}$-cadherin & 114020 & nd & Blood-testis barrier integrity & [123] \\
\hline Nef & - & MD / GED & HIV-1 entry & [149] \\
\hline Nostrin & 607496 & PRD & eNOS trafficking & {$[150]$} \\
\hline N-WASp & 605056 & nd & Actin remodelling & {$[75]$} \\
\hline Occludin & 602876 & nd & Blood-testis barrier integrity & [123] \\
\hline p85 & 171833 & PRD & & [138] \\
\hline PDE $\gamma$ & 180073 & nd & Cell signalling & {$[151]$} \\
\hline PLC $\gamma$ & 172420 & PRD & & [138] \\
\hline PLD2 & 602384 & nd & Cell signalling & {$[152]$} \\
\hline Shank 1 & 604999 & PRD & Postsynaptic membrane turnover & [153] \\
\hline Pyk2 & 601212 & nd & Podosome dynamics & [154] \\
\hline Shank 2 & 603290 & PRD & Postsynaptic membrane turnover & {$[153]$} \\
\hline SNX9 & 605952 & PRD & Membrane remodelling - actin dynamics & {$[38,155]$} \\
\hline SNX18 & - & PRD & Endosomal trafficking & [155] \\
\hline SNX30 & - & PRD & Membrane trafficking? & [155] \\
\hline
\end{tabular}




\begin{tabular}{|l|l|l|l|l|}
\hline Syndapin 2 & 604960 & PRD & Vesicle formation from the TGN & {$[59]$} \\
\hline Syndecan-4 & 600017 & PH & Actin stress-fibers and focal adhesion sites & {$[81]$} \\
\hline Tks5/FISH & - & PRD & Cell signalling & {$[156]$} \\
\hline TULA & 605736 & nd & EGFR trafficking & {$[157]$} \\
\hline Vav1 & 164875 & PRD & T cell activation by actin remodelling & {$[158]$} \\
\hline$\beta$-tubulin & 191130 & PRD & & {$[18]$} \\
\hline$\gamma$-adaptin & 603533 & PRD & & {$[18]$} \\
\hline$\gamma$-tubulin & 191135 & MD & Centrosome cohesion & {$[84]$} \\
\hline ZO1 & 601009 & nd & Blood-testis barrier integrity & {$[123]$} \\
\hline
\end{tabular}

Abp1: actin binding protein. CAP: CBL associated protein. CBL: Cas-Br-M murine ecotropic retroviral transforming sequence homolog. CIP4: cdc42 interacting protein-4. eNOS: endothelial nitric-oxide synthase. Ese1: EH domain and SH3 regulator of endocytosis 1. FAK: focal adhesion kinase. FBP17: Formin-binding Protein 17. Grb2: growth factor receptorbound protein 2. IL-5R $\alpha$ : $\alpha$ subunit of the interleukin 5 receptor. Jak2: Janus kinase 2. JAMA: junctional adhesion molecule A. KDR: kinase insert domain receptor also known as Vascular endothelial growth factor receptor-2. MLK2: mixed-lineage kinase 2. Nef: accessory protein of the HIV-1. N-WASp: Wiskott Aldrich syndrome protein. PDE $\gamma$ : inhibitory $\gamma$ subunits of the retinal cGMP phosphodiesterase. PLC $\gamma$ : Phospholipase C gamma 1. PLD2: phospholipase D2. SNX9: sorting nexin 9. Tks5/FISH: tyrosine kinase substrate 5/five SH3 domains. TULA: Cbl- and ubiquitin-interacting protein T-cell ubiquitin ligand. Vav1: Rho family guanine nucleotide exchange factor Vav1. ZO1: Zonula occludens 1. 

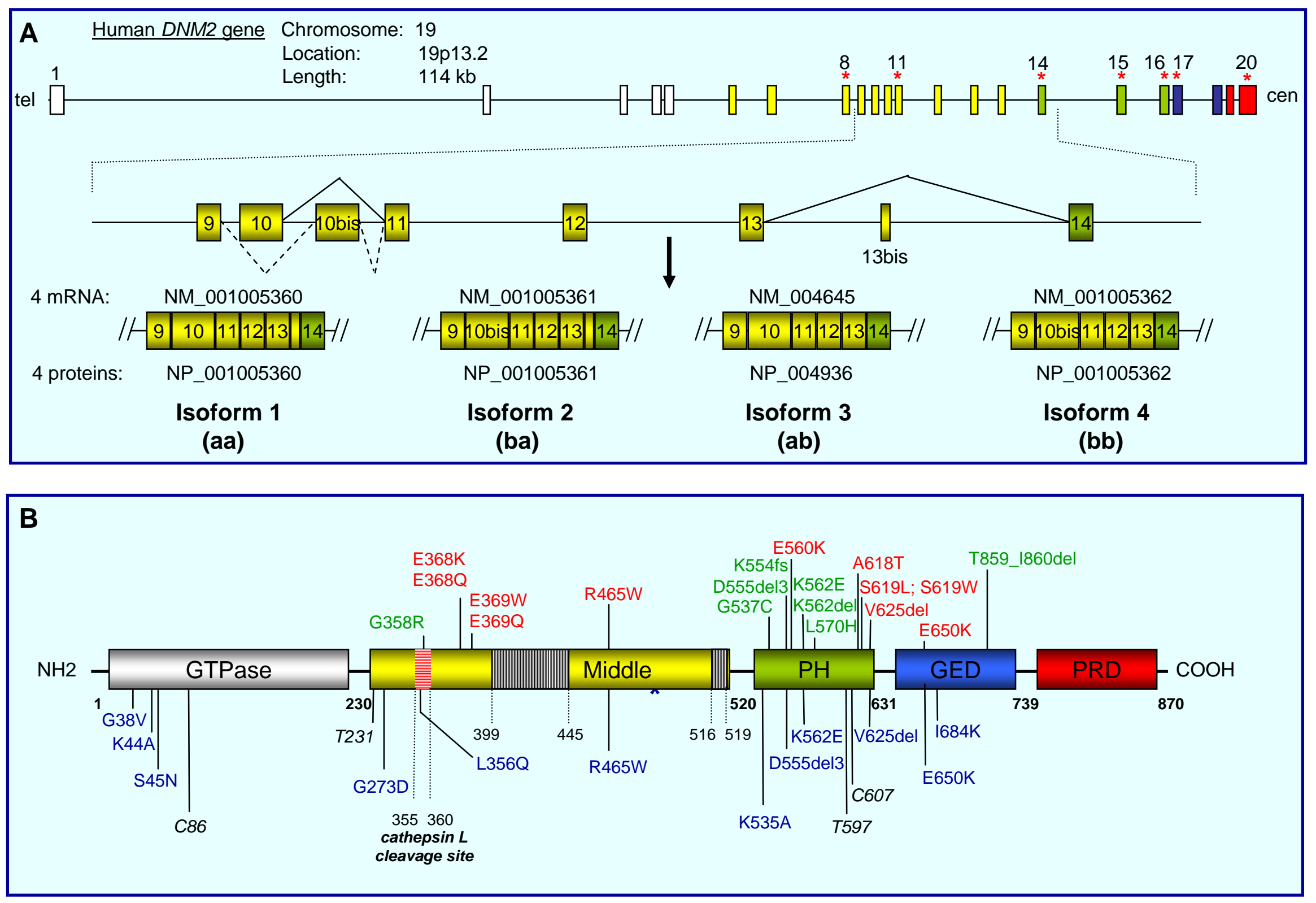


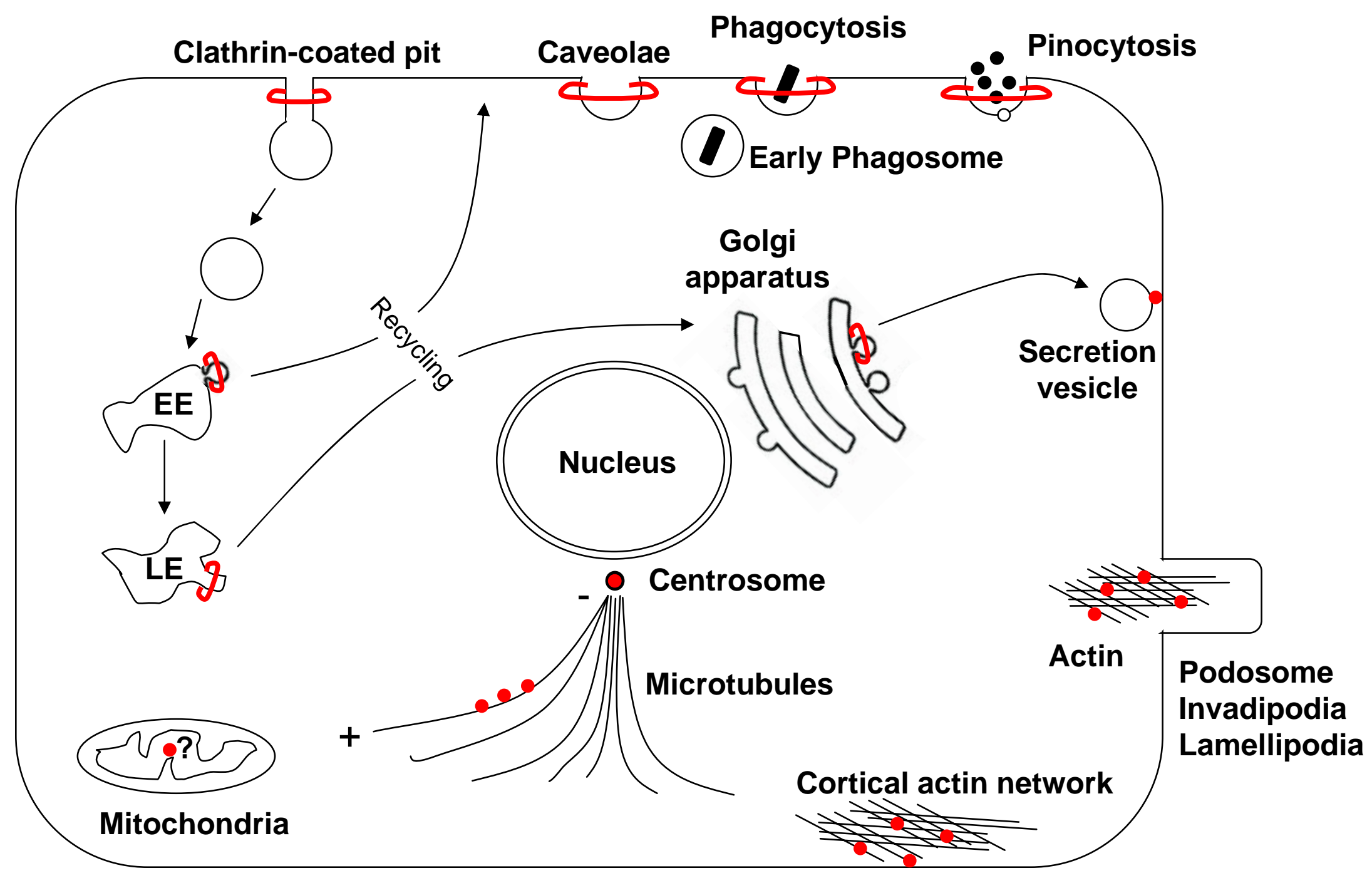

